\title{
An empirical study on long-term relationship between total factor productivity and non-oil exports in Iran
}

\author{
Teymour Mohammadi ${ }^{a}$ and Samane Abooali ${ }^{\mathbf{b}^{*}}$
}

${ }^{a}$ Assistant Professor, Department of Economics, Science and Research Branch, Islamic Azad University, Tehran, Iran ${ }^{b}$ Department of Economics, Science and Research Branch, Islamic Azad University, Tehran, Iran Student of Economics

\section{CHRON I C L E}

\section{Article history:}

Received May 18, 2013

Received in revised format

28 August 2013

Accepted 1 September 2013

Available online

September 12013

Keywords:

Total factor productivity

Non-oil exports

Vector error correction model

\section{A B S T R A C T}

\begin{abstract}
This paper presents an empirical investigation on the effect of exports of non-oil goods and services on economic growth in Iran over the period 1991-2011 using Vector Autoregressive method. We also analyze the existing causal relationships between total factor productivity and non-oil exports. The results show that total factor productivity has direct and significant relationship with non-oil exports in long-term, it means that if total factor productivity increases, non-oil exports also increases. The results of the survey also indicate that the existing shock on non-oil exports does not have any significant impact on total factor productivity but the incoming shock on total factor productivity reduces non-oil exports during the first period. It also increases non-oil exports during the first period to the fourth period and from the fifth period; it continues until it reduces to a small amount, remains in that amount and eventually disappears.
\end{abstract}

\section{Introduction}

Many economists believe that export or import provides the promotion capabilities to increase productivity growth and more competition in import leads to more efficiency of corporations. In addition, the increase on import due to the possibility of using the new technical information by exporting corporation improves the efficiency of these corporations (Aw \& Hwang, 1995). In addition, in modern economy, there is a direct relationship between the degree of a country's development and the volume of that country's international business relations. Therefore, development of export and gaining more exchange resources are the most important goals of countries' economic policymakers. Export helps increase the production rate and employment through excitation of domestic production. Exporting goods and services also provide the required exchange resources in order to increase the import and domestic consumption that cause the

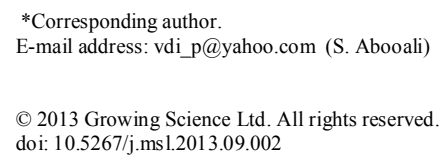


increasing of economic welfare. An increase in exports is the primary concern of most governments in recent decades (Nazemi, 2010).

Developing exports is as factor, which helps organizing production for larger markets and consequently it helps to reach more efficient production methods and less costly because of intensity of competition in that markets. In addition, trade issue and export development facilitate people to become more familiar with new products also motivate underdeveloped countries. In some countries where there are rich sources of oil and gas, government policies mainly depend on export of such products and there will be less motivation on creating value added products. In economy relies on oil rent a significant proportion of the country's wealth is because of oil not work force. This matter weakens workforce's motivation, as part of the production factors for hard working and economic competitiveness. Because oil rent is easier trough achieving to oil wealth than creating wealth through working and creativity. The failure of most countries which followed import substitution strategy and this fact that newly industrialized countries of Asia mostly have been able to maintain and strengthen its economy's continuous growth through export development strategy and influence on global markets.

One of the export growth and development's factor is increasing labor productivity, capital and total factor productivity. Emphasizing on productivity is so high that some of them blame underdeveloped countries for low productivity. In the current situation, higher efficiency and utilization of existing facilities have become a necessity. Investigating different components of economic growth in developed and developing countries shows that the share of total factor productivity increases more than the share of investment increase. The main element of any production system is associated with the resources and capabilities including manpower and capital. While each system could use of resources effectively and with maximum efficiency, we do not know whether it was useful or it was considered as an appropriate combination of production factors and there were not any surplus resources on it (Moghimi \& Jalali, 2007).

Export activity is considered as essential component of independent demand function as increasing coefficient influences on investment and production. In addition, export growth may cause the reallocation of existing resources from noncommercial sector to the export sector to increase total factor productivity. Export is a tool for production and currency flows to domestic economy and these currencies supply related financial requirements for import or other necessary goods and services. In addition, tendency to foreign perhaps through benefiting from economies scales and subsequent behaviors of international contracts creates more efficiency among corporations. In some special cases, we can say that economic growth increases necessary skills and technologies, which play significant role in creation of comparative advantages in international level and consequently trade development. However, flows of trade development, exports and imports have important role in creation of economic growth and development similarly but most economists have concentrated on export and its impact on economic growth.

Michaely (1977) reported a positive relationship between the ratio of exports to GDP and GDP growth rate for a group of developing countries. Balassa (1978) examined relationship between exports and economic growth for 11 developing countries over the period 1960-1973, and reported that export growth could influence on economic growth rate, significantly. Tyler (1981) extended Balassa's work, tested the model for 55 countries and reported that there was a significant and positive relationship between economic growth and total exports. Ram (1985) examined the share of exports on economic growth by using the production function for some under developed countries over the period 1960-1970 and reported a significant effect of exports on economic growth. Mbaku (1988) studied on the relationship between exports growth with using of production function approach in low-income countries and middle-income countries in Africa and reported that the effect of exports on growth was more severe in low-income countries than the effect in middle-income countries was. 
There are literally few studies on causality relationship between economic growth and export growth. Some studies express a one-way relationship and others mutual relationship. Other studies show that enterprises with high performance and productivity can access to export markets and we may not claim that export increases efficiency. However, if exporters with high performance develop industry and the possibility generate more production factors, this increases the industry productivity levels through entering more enterprises in exports era.

Generally, it is believed that a combination of higher levels of productivity and faster economic growth can motivate more people to participate in export activities. In addition, the empirical evidence shows enterprises accessibility to export markets and selling goods in international markets may also help enterprises increase their performances. Therefore, trade liberalization has positive impact on different levels of productivity and even in further step on the long-term growth rates of productivity for developing countries. Nevertheless, there is not a crystal clear evidence about positive relationship between trade liberalization and productivity growth.

Krishna and Mitra (1988) studied on the effects of trade liberalization on competitiveness and productivity in India in 1991. They used productivity measuring technique designed by Solow (1957) and estimated changes in multifactor productivity based on panel data about industrial enterprises over the period 1986-1993 and analyzed the data by using random effects estimation's method. They reported that all industries except electrical machinery, observed reducing in returns to scale after 1991. Decreasing return to scale, according to total share of factors such as labor, primary materials and fuels were changed so much in sample after trade liberalization and retail pricing reduced so much.

Sjöholm (1999) studied the effect of foreign trade on firm productivity growth through total exports and imports of goods' intermediate input. The results showed a positive relationship between growth in the share of labor and investment to GDP. Growth coefficient of labor, in this study, was larger and capital coefficient was very small. Filiztekin (2000) examined the relationship between trade policy and growth in Turkish industry over the period 1996-1970. They reported that five top industries in terms of value-added in the beginning of period 1980-1970 had lower growth after. Based on his results after liberation, evidence showed the lower growth of import but all industries had faced with increase in export. The increase share in leather industry and electrical machinery was more than other industries.

Tehranchian (2002) studied the effect of export on Iran's economic growth and reported that within a 30 -year period of investigation, the non-oil export was formed averagely just 5.7 percent of total export and 1.6 percent of country GDP. While the oil exports up to year1996 was accounted for more than 90 percent of GDP by itself. Atrkar Roshan (2008) studied export expansion and economic growth before and after the Iranian 1979 revolution and reported that in both stages there was a positive relationship between export expansion and economic growth. Tehranchian (2009) studied the effect of import on Iran's economic growth where the investigation of import process showed that despite the increase of import, all three groups of these goods, combination of imported goods especially after the implementation of development programs were changed in favor of intermediary goods and capital. Cetinkaya \& Erdogan (2010) studied the import-export data in Turkey over the period 2002-2010 by applying VAR Analysis. They determined that there was causality relationship between GDP and export.

Maleki (2011) studied the effect of export technological composition on economic growth. In their study, the estimation of time series model with two techniques at least simple normal squares and augmented confirmed the hypothesis of efficiency differentiation in utilization of production factors, in sectors of technology export. He also believed that technology sectors on non-oil export had more effect on growth. Pistoresi and Rinaldi (2011) investigated the nexus between trade and economic 
growth in Italy and contributed to fill an existing gap by investigating the relationship between real exports, imports and GDP in Italy over the period 1863-2004 by using cointegration analysis and causality tests. The outcome suggested that these variables commove in the long run but the direction of causality varies across time. In the period prior to the First World War import growth led GDP growth that in turn led export growth. Conversely, in the post-Second World War period they found a strong bidirectionality between imports and exports consequent on the increase in intra-industry trade. They also reported a weak support for export-led growth and growth-led imports. Now, in the present study the main goal knows long-term relationship between total factor productivity and non-oil exports.

\section{Analysis of data}

This survey uses the vector autoregressive pattern, which is suitable analytical model for analytical pattern. After considering previous studies, the pattern of Ogunleye and Ayeni (2008) was chosen as the basis for the proposed model of this paper. The logarithmic model tested in this study is as follows:

$$
\mathrm{LOG}(\mathrm{TFP})=f(\mathrm{LOG}(\mathrm{EXPN}), \mathrm{LOG}(\mathrm{MCG}), \mathrm{LOG}(\mathrm{REP})),
$$

where TFP is total factor productivity, EXPN stands for non-oil exports, MCG is associated with import of capital goods and Rep represents important tax rate.

\subsection{The unit root test of Augmented Dickey Fuller}

In this part, the augmented Dickey-fuller test is performed for mentioned variables and the results have been reported briefly in Table 1 .

\section{Table 1}

The results of the unit root test of augmented Dickey-fuller for the model's time series data

\begin{tabular}{|c|c|c|c|c|c|c|c|}
\hline \multirow{2}{*}{$\begin{array}{l}\text { Series } \\
\text { Name }\end{array}$} & \multirow{2}{*}{$\begin{array}{l}\text { Statistics of } \\
\text { augmented }\end{array}$} & \multirow{2}{*}{$\begin{array}{l}\text { Statistics of } \\
\text { augmented }\end{array}$} & \multicolumn{3}{|c|}{ critical values of } & \multirow{2}{*}{ prob } & \multirow{2}{*}{ Explanations } \\
\hline & & & $\% 1$ & $\% 5$ & $\% 10$ & & \\
\hline LTFP & - & -2.40 & -2.69 & -1.96 & -1.60 & 0.0193 & With first difference became static \\
\hline LNEXPN & - & -4.00 & -2.69 & -1.96 & -1.60 & 0.0004 & With first difference became static \\
\hline LNREP & - & -4.71 & -2.69 & -1.96 & -1.60 & 0.0001 & With first difference became static \\
\hline LNMCG & - & -6.73 & -2.69 & -1.96 & -1.60 & 0.0000 & With first difference became static \\
\hline
\end{tabular}

As seen from the results of Table 1, all variables including, total factor productivity, non-oil exports, import of capital goods, important tax rate became static after applying the first difference.

\section{Result}

\subsection{Length determination of model's optimal Lag}

After selecting the used variables in model as well as static test, the length determination of optimal lag is an important issue in VAR model. The proposed model of this paper uses Akaike, Schwarz, Hannan-quinn, FPE, LR information criteria for length determination of optimal lags and offers second lag as optimal lag length for this model. Therefore, the length of optimal lag is 2 and the obtained results for the length determination of optimal lag are shown in Table 2 as follows,

Table 2

Determination of optimal lag length

\begin{tabular}{lllllll}
\hline Lag & LogL & LR & FPE & AIC & SC & HQ \\
\hline 0 & -273.56 & NA & 57464878 & 29.21 & 29.41 & 29.25 \\
1 & -216.83 & 83.61 & 829879.1 & 24.92 & 25.92 & 25.09 \\
2 & -162.67 & $57.01^{*}$ & $19738.73^{*}$ & $20.91^{*}$ & $22.70^{*}$ & $21.21^{*}$ \\
\hline
\end{tabular}




\subsection{Johansson's cointegration test}

In this paper, Johansson's cointegration test was performed for variables I(1) including total factor productivity, non-oil exports, import of capital goods, important tax rate and they are reported in Table 3. It is worth to mention that after applying test with variables I (1) model's estimation will be done through VECM. As seen from the results of Table 3, according to both the maximum eigenvalue and trace test, there are 3 cointegration vectors. In other words, there is a linear combination of variables, which the static was grade A. So with assurances of about the not existing of false regression can use of all variables as level.

Table 3

Johansson's cointegration test

\begin{tabular}{|c|c|c|c|c|}
\hline \multicolumn{5}{|c|}{ Cointegration Rank Test(Trace) } \\
\hline Hypothesized No. of & Eigenvalue & Trace Statistic & 0.05 Critical Value & Prob. ${ }^{*}$ \\
\hline None * & 0.97 & 117.67 & 47.85 & 0.00 \\
\hline At most $1 *$ & 0.77 & 46.99 & 29.79 & 0.00 \\
\hline At most $2 *$ & 0.54 & 18.24 & 15.49 & 0.01 \\
\hline \multicolumn{5}{|c|}{ Cointegration Rank Test(Maxium Eigenvalue) } \\
\hline None* * & 0.97 & 70.68 & 27.58 & 0.00 \\
\hline At most $1^{*}$ & 0.77 & 28.74 & 21.13 & 0.00 \\
\hline At most $2^{*}$ & 0.54 & 14.83 & 14.26 & 0.04 \\
\hline
\end{tabular}

\subsection{The Estimation of Error Correction Model}

After model estimating as vector error correction method, the results are summarized in Table 4 as follows.

Table 4

The result of vector error correction model estimation

\begin{tabular}{llll}
\hline Cointegrating Eq & CointEq1 & Standard errors & t-statistics \\
\hline LNEXPN(-1) & 1.00 & - & - \\
LTFP(-1) & $-1.35 \mathrm{E}-05$ & $2.5 \mathrm{E}-06$ & -5.31 \\
LREP(-1) & -0.79 & 0.15 & -5.28 \\
LMCG(-1) & -0.76 & 0.08 & -8.85 \\
CointEq1 & -0.65 & 0.07 & -8.55 \\
\hline
\end{tabular}

One of the patterns raised in the case of existing long-run equilibrium relationship about time series is associated with the effects of error correction model. Related coefficient to error arising from longrun equilibrium relationship is called as adjustment coefficient and indicates speed adjustment from deviation from the long-term equilibrium. As seen from the results of Table 4, this coefficient is significant and its value is 0.65 . This means that $65 \%$ of deviations and volatility is adjusted towards the long-term equilibrium in the first year.

Total factor productivity has significant and direct relationship with non-oil exports and it means that if total factor productivity increases about $1 \%$ then non-oil exports will increase about $0.00001 \%$, which means that total factor productivity has significant and positive effect on non-oil exports but the effect is minor. Important tax rate has significant and direct relationship with non-oil exports, which means that if important tax rate increases about $1 \%$, then non-oil exports will increase about $0.79 \%$. On the other hand, import of capital goods has significant and direct relationship with non-oil exports, which means that if import of capital goods increases about $1 \%$, then the non-oil exports will increase about $0.76 \%$. 


\subsection{Impulse, response function}

Impulse, response function shows dynamic behavior of the variables during the time of shocking about one standard deviation from other variables. In other words, one impulse, response function shows response that system's endogenous variable gives to shocks arising from errors. In this part, dynamic response of total factor productivity's variable is shown in Fig. 1 due to shocking in other variables and based on Cholesky analysis for the following 10 periods.

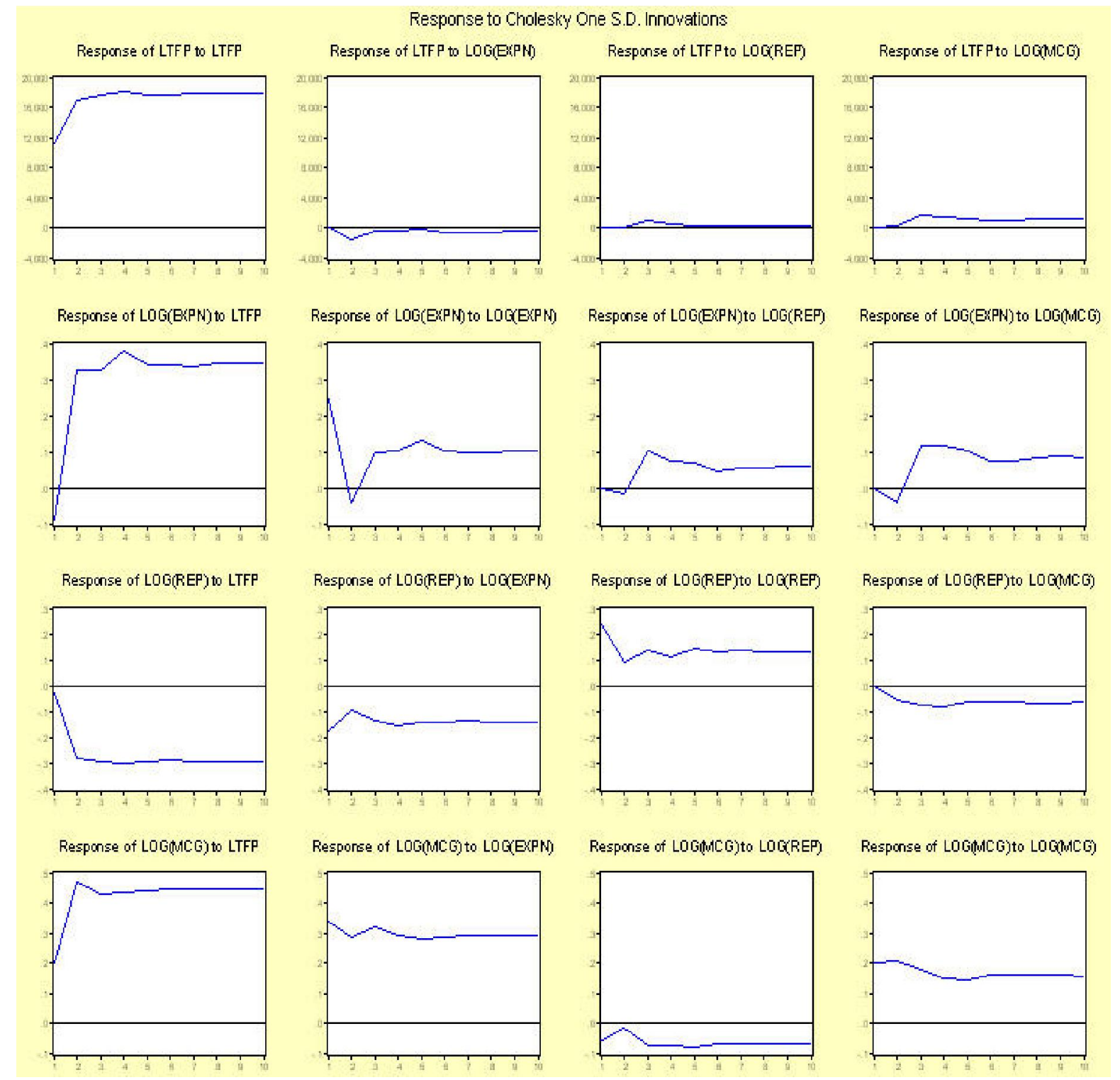

Fig. 1. The response of every variable to the shocks from other variables

Based on the results of Fig. 1, the existing shock on non-oil exports does not have any significant impact on total factor productivity but the incoming shock on total factor productivity reduces non-oil exports during the first period. It also increases non-oil exports from the first period to the fourth period and from the fifth period it continues until it reduces to a small amount, remains in that amount and disappears. 


\section{Discussion and Conclusion}

According to the results of this survey, it can be stated that 2-length lag was proposed as an optimal lag length for the model, which was also based on vector error correction model. Total factor productivity had significant and direct relationship with non-oil exports in long-term, which means as the total factor productivity increases, non-oil exports will increase too.

In addition, the variables of total factor productivity, tax rate and import of capital goods had significant and direct relationship with non-oil exports. Therefore, for increasing non-oil exports we need to have appropriate plan with accurate and comprehensive planning and investment. In addition, by accurate surveying on opportunities and threats facing Iran's economy, globalization can remove existing limitations and weakness in country's infrastructures related to export in different areas such as transportation, terminals, packing, rail road, air, sea, etc.

\section{Acknowledgment}

The authors would like to thank the anonymous referees for constructive comments on earlier version of this paper.

\section{References}

Atrkar Roshan, S. (2008). Export expansion and economic growth, evidences of Iran after the revolution period. Journal of Social and Human Sciences, 26, 111.

Aw, B. Y., \& Hwang, A. R. M. (1995). Productivity and the export market: A firm-level analysis. Journal of Development Economics, 47(2), 313-332.

Balassa, B. (1985). Exports, policy choices, and economic growth in developing countries after the 1973 oil shock. Journal of Development Economics, 18(1), 23-35.

Cetinkaya, M., \& Erdogan, S. (2010). VAR Analysis of the Relation between GDP, Import and Export, Turkey Case. International Research Journal of Finance and Economics, 55, 135-145.

Filiztekin, A. (2000). Openness and productivity Growth in Turkish manufacturing. Yale University (Australia).

Krishna, P., \& Mitra, D. (1998). Trade liberalization, market discipline and productivity growth: new evidence from India. Journal of Development Economics, 56(2), 447-462.

Michaely, M. (1977). Exports and growth: an empirical investigation. Journal of Development Economics, 4(1), 49-53.

Maleki, A. (2011). The effect of export technological composition on economic growth. Journal of Commerce, 14(56), 149-176.

Mbaku, J. M. (1988). Political instability and economic development in Sub-Saharan Africa: Some recent evidence. The Review of Black Political Economy,17(1), 89-111.

Moghimi, F., \& Jalali, Gh. (2007). The study of measuring Total factor productivity's index about Economic Enterprises, case study about SAIPA Company. Economic Studies, 27, 39-50.

Nazemi, F. (2010). The study of macroeconomic variables effect on non-oil exports. Industrial Management Journal of Humanities College, Islamic Azad University, Sanandaj Branch, 4(10).

Ogunleye, E. O., \& Ayeni, R. K. (2008). The link between export and total factor productivity: Evidence from Nigeria. Social Sciences, 1, 9-18.

Pistoresi, B., \& Rinaldi, A. (2012). Exports, imports and growth: New evidence on Italy: 18632004. Explorations in economic history, 49(2), 241-254.

Ram, R. (1985). Exports and Economic Growth: Some Additional Evidence. Economic Development and Cultural Change, 33: 415-25.

Sjöholm, F. (1999). Exports, imports and productivity: results from Indonesian establishment data. World Development, 27(4), 705-715.

Solow, R. M. (1956). A contribution to the theory of economic growth. The quarterly journal of economics, 70(1), 65-94. 
Tehranchian, A M. (2002). Export effect on Iran's economic growth. Journal of Political - Economic Information, 164, 258-267.

Tehranchian, A M.(2009). Import effect on Iran's economic growth. Journal of Political - Economic Information, 258, 192.

Tyler, W. G. (1981). Growth and export expansion in developing countries: some empirical evidence. Journal of Development Economics, 9(1), 121-130. 